Vanderbilt University has been endowed with

a \$1 million gift by alumni Poppy and Richard Buchanan for a program that creates in-depth learning experiences for undergraduate students with diverse library resources. The Poppy Pickering Buchanan and Richard D. Buchanan Library Fellows Fund will benefit students and future library users by supporting strategic projects in which selected students work on multidisciplinary teams under the mentorship of faculty and professional librarians.

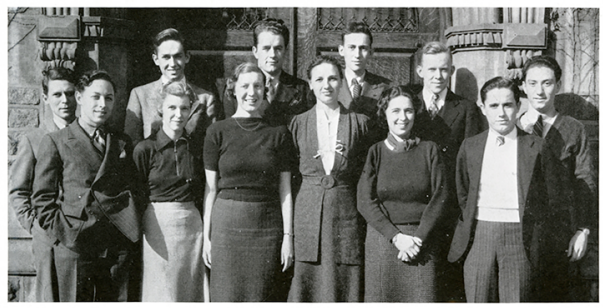

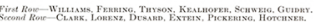

\title{
Washington University
}

in St. Louis (WUSTL) Libraries has been awarded a $\$ 50,000$ grant from Newman's Own Foundation, the independent foundation created by the late actor and philanthropist, Paul Newman. The award to the libraries was made by Newman's Own Foundation as part of its commitment to

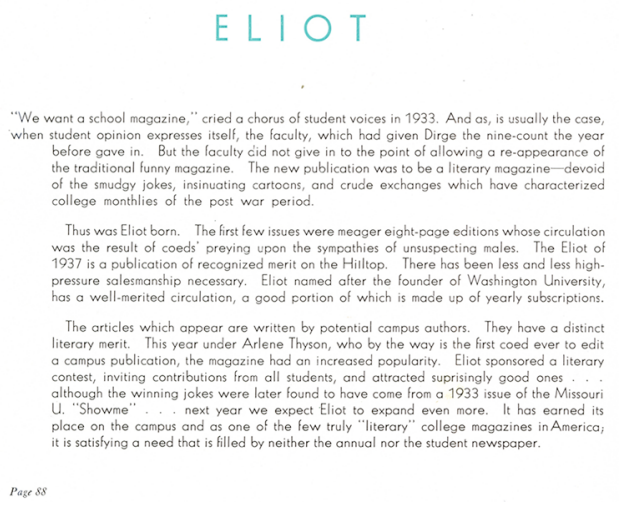

A page from Washington University's student yearbook, The Hatchet. helping nonprofit groups. The grant to the libraries will be used to support teaching and learning at WUSTL and beyond by enabling the further development and accessibility of collections related to literature, the performing arts, and university history. Funds from the grant will be used to process the papers of memoirist, novelist, playwright, and biographer A. E. Hotchner, a WUSTL alumnus and cofounder of Newman's Own Inc., and

Ed. note: Send your grants and acquisitions to AnnChriste Galloway, production editor, C\&RL News, email: agalloway@ala.org. the papers of poet, novelist, and playwright David Wagoner. The grant also will be used to support recent and upcoming acquisitions for the Modern Literature Collection and to digitize student publications in the University Archives, including the student yearbook, The Hatchet (1903-2011); the student newspaper, Student Life (1878-present); The Eliot Literary Magazine (1915-47), and the Dirge magazine (1919-34), which focused on humor, satire, and cartoons.

\section{TheWakeForestUniver-}

sity Z. Smith Reynolds Library Special Collections and Archives (SCA) has received a Council on Library and Information Resources (CLIR) Recordings at Risk Grant. CLIR will provide $\$ 50,000$ for "Documenting the Evangelical Movement in the United States: Digitizing Baptist State Convention of North Carolina Open-Reel Audiotapes, 1957-1980." George Blood LP will reformat and digitize approximately 1,500 at-risk and rare open-reel audio recordings for SCA. The open-reel tapes document the American evangelical movement and contain presentations by prominent Southern Baptist pastors and church representatives at evangelical conferences and annual meetings of the Southern Baptist Convention. The speakers and programs on the tapes document the denomination's activities and subjects of discussion (1957-80) ranging from Baptist theology to broad cultural and societal issues. 
This project will result in the long-term preservation digital storage for these tapes, and broad access through the Wake Forest University North Carolina Baptist Portal currently being developed. Once completed, there will be an active outreach program, focused on demonstrating how historians, researchers, and religious scholars can use these records in their research and teaching. The speakers include prominent Southern Baptist leaders, such as Kenneth Chafin, Billy Graham, Dale Moody, Wayne Oates, and Stephen Olford. The subjects range widely, from internal Baptist concerns relating to baptism and dancing at Baptist colleges, the role of the church in an increasingly liberal society, missionaries working abroad, political involvement, and the role of women.

\section{The American University of Paris (AUP) has been}

awarded a \$1.1 million three-year grant by the Andrew W. Mellon Foundation for "Building Leadership and Capacity for Digital Liberal Arts across AMICAL." Founded and hosted by AUP, AMICAL is a consortium of 27 American-style liberal arts institutions in 21 countries across Europe, Central and Southern Asia, the Middle East, and Africa. The grant uses digital scholarship and pedagogy as a focal point for bringing librarians, faculty and technologists to work together on their shared teaching and learning missions.

\section{The Binghamton University Libraries has}

been awarded a $\$ 15,000$ grant from the Gladys Krieble Delmas Foundation to digitize the Max Reinhardt Collection. The collection covers major aspects of the life and career of Austrian-born theatrical director and producer Max Reinhardt (1873-1943). Reinhardt was widely recognized as a major creative artist and played a leading role in the transformation of the director as the key figure in theatrical production and the innovative use of new theater technology and experimentation with theater spaces and locales. The grant provides funding to preserve, digitize, and publish online a col- lection of 132 promptbooks from the collection, which are annotated by the director himself. The project will make this historical record available to researchers and the public, giving them new perspectives on his work and theater history. The libraries will hire interns to convert the promptbooks into digital files that will be discoverable online via search engines and can be widely shared. The project will last from May 2018 through April 2019.

\section{Acquisitions}

\section{The Joy Williams Papers, a collection of} drafts, journals, correspondence, and other materials related to the life and work of author Joy Williams, has been acquired by the Washington University in St. Louis (WUSTL) Libraries, with support from the WUSTL Department of English. An acclaimed fiction writer and essayist, Williams is the author of four novels, five short-story collections, and one essay collection. Her short stories are widely anthologized. Her first novel, State of Grace (1973), was nominated for the National Book Award. Her 2000 novel, The Quick and the Dead, was nominated for the Pulitzer Prize, and her 2001 essay collection, Ill Nature: Rants and Reflections on Humanity and Other Animals, was a finalist for the National Book Critics Circle Award. Williams is the recipient of a Guggenheim fellowship, a National Endowment for the Arts grant, and the Harold and Mildred Strauss Living Award from the Academy of Arts and Letters. This year, The Paris Review will present her with the Hadada Award for lifetime achievement. Williams has taught creative writing at institutions across the country, including the University of Iowa and the University of Wyoming, where she is visiting eminent writer-in-residence. The materials in the Joy Williams Papers span her entire life, and the purchase includes future papers. The Joy Williams Papers will be processed, cataloged, and available for research later this year. $\boldsymbol{Z}$ 